\title{
Anmeldelse: Putins selektive retfærdighed
}

Af Vibeke Sperling

Vil man forstå magtspillet i Rusland er Richard Sakwas bog en guldgrube. Den underbygger, at Jukos-affæren og regimets behandling af Khodorkovskij er den mest afgørende indenrigspolitiske begivenhed i Putins Rusland. Det blev konflikten, der formede den postsovjetiske stat under Putin

Richard Sakwa: Putin and the Oligarch. The Khodorkovsky-Yukos Affair. I.B. Tauris 2014

Verdens opmærksomhed har i måneder været koncentreret om de helt nye relationer mellem Rusland og Vesten som følge af Ruslands annektering af Krim og Moskvas krig per stedfortræder i det østlige Ukraine. Men vil man forstå magtspillet internt $\mathrm{i}$ Rusland, er Richard Sakwas bog Putin and the Oligarch en guldgrube. Kun en forfatter med så dyb indsigt i det moderne Rusland kunne levere en bog ganske kort tid efter den overraskende benådning og løsladelse af den tidligere oliemagnat Mikhail Khodorkovskij i december sidste år. Sagen om Khodorkovskij og hans olieselskab Jukos skabte det økonomiske system, som hersker i Rusland i dag.

Sakwa giver en livlig, afbalanceret og klog fortælling om opstigningen og faldet for Ruslands engang rigeste mand, tidligere chef for Jukos, som Khodorkovskij gjorde til Ruslands mest velfungerende virksomhed i nyere tid. Men Khodorkovskij blev i oktober 2003 arresteret og dømt for økonomisk kriminalitet, lige da Jukos var ved at gå globalt. Bogen underbygger opfattelsen af, at Jukos-affæren og regimets behandling af Khodorkovskij er den mest afgørende indenrigspolitiske begivenhed i Vladimir Putins Rusland.

Det blev konflikten, der formede den postsovjetiske stat i Putins billede.

\section{Fra Komsomol til Jukos}

Og Khodorkovskijs løsladelse den 20. december »blev en af de mest forbløffende begivenheder i moderne russisk historie«, skriver Sakwa. Med en imponerende detaljerigdom fortælles Khodorkovskijs historie fra hans centrale placering i kommunistpartiets ungdomsorganisation Komsomol, til han blev oligark. Organisationen blev i Mikhail Gorbatjovs tid set som lokomotivet til at omdanne Rusland til en moderne 
Khodorkovskij var med til at danne en af Ruslands første private banker, Menatep, der stod parat med pengene til at købe sig ind i energisektoren efter kommunismens fald. Med Khodorkovskij som en af arkitekterne blev det til det omstridte 'lån for aktier'- program, der indebar at oligarkerne lånte staten penge og fik lukrative aktier til gengæld.

stat, nok styret fra Kreml, men med en dynamisk markedsøkonomi.

Komsomol forsvandt, men ikke dens rigdomme, hvoraf Khodorkovskij disponerede over en del. Sovjetunionens sammenbrud betød sammenbrud også for autoritet. Statsmagten mistede grebet om sin egen ejendomsret. Det var Khodorkovskij en af de mest initiativrige til at berige sig på, som bogen blotlægger.

Khodorkovskij var med til at danne en af Ruslands første private banker, Menatep, der stod parat med pengene til at købe sig ind i energisektoren efter kommunismens fald. Med Khodorkovskij som en af arkitekterne blev det til det omstridte 'lån for aktier'-program, der indebar at oligarkerne lånte staten penge og fik lukrative aktier til gengæld.

Khodorkovskij og mange andre fik store lunser af arvesølvet i energisektoren.

Da han overtog olieselskabet Jukos, var det et dårligt drevet foretagende, hvor de sovjetiske vaner dominerede. Men han gjorde det til Ruslands mest dynamiske og mest gennemskuelige virksomheder.

\section{En politisk udfordring}

Khodorkovskij var en politisk udfordring for regimet, »og hans handlinger gjorde de andre oligarker nervøse. Så Khodorkovskij var castet til sin skæbne«, skriver Sakwa.

Da maskerede mænd fra efterretningstjenesten FSB's antiterrorenhed arresterede ham i Novosibirsk lufthavn ved daggry 25. oktober 2003, var han i færd med at ekspandere langt ud over Rusland. Han forhandlede med kineserne om en olieledning til Kina, og han havde tilbudt BP 25 pct. af aktierne i Jukos.
Kreml sagde nej til eventyret med Kina, da Khodorkovskijs vej ud i verden var i modstrid med Putins ønske om at gennationalisere 'strategiske sektorer', som energisektoren var krumtappen i.

Blandt de mange afgørende fodaftryk, som Yukos-affæren har sat i Rusland, er den såkaldte Basmannij-retfærdighed, dvs. regimets brug af Basmannij-domstolen i Moskva i sit politiske korstog mod Khodorkovskij. Dertil kom, at Khodorkovskij finansierede store dele af Ruslands græsrødder samt politiske partier. Han ønskede at få Jukos-tilhængere i underhuset, Dumaen, ved valget i 2003, men Putin slog til imod ham inden.

Putin spillede dygtigt på hadet til oligarkerne i en russisk befolkning, som havde set dem stjæle arvesølvet under 1990'ernes lyssky privatiseringer. Khodorkovskij var med på den vogn, men der var tale om 'selektiv retfærdighed', da alle oligarker skulle fængsles, hvis alle skulle behandles som Khodorkovskij.

Da Putin kom på præsidentposten i 2000, proklamerede han, at han ville eliminere 'oligarkerne som klasse'. Men det blev, som Sakwa påviser, en selektiv affære. På et møde kort efter at Putin rykkede ind i Kreml, gjorde han oligarkerne klart, at han ikke ville røre ved de besiddelser, som de havde erhvervet under 1990'ernes problematiske privatiseringer under hans forgænger, Boris Jeltsin. Til gengæld skulle oligarkerne opgive deres hidtil store politiske magt.

Den handel respekterede Khodorkovskij ikke og investerede ikke alene i oppositionspartier, men også i projekter i overensstemmelse med sin vision om Ruslands 
demokratiske fremtid, herunder i et utal af uddannelsesprojekter.

\section{En af verdens mest magtfulde fanger}

Men først under fængselsopholdene - næsten to år i varetægtsfængsel i Matrosjka Tisjina fængslet i Moskva, derefter i en fangelejr i Chita i Sibirien og de sidste par år i fangenskab i Karelen - blev han omdannet fra oligark til dissident og filantrop og blev 'en af verdens mest magtfulde fanger, som Sakwa skriver:

"Befriet fra byrden med Jukos vendte han sin opmærksomhed til emner som offentlig politik og politisk udvikling. Han distancerede sig fra Jukos' anliggender til fordel for landets skæbne".

Khorokovskij udsendte fra fangenskab en strøm af interviews, artikler og essays, som i det store og hele undgik direkte kritik af arvefjenden Putin, men fokuserede på selve systemets korrupte logik.

Som svar på læserbreve i magasinet Bolsjoj Gorod, lige efter at Khodorkovskij havde fået sin første dom i 2005, fremlagde han sit syn på 'russisk frihed'. Han indledte med den ret paradoksale erklæring: "Jeg er taknemmelig over fængslingen, fordi det har givet mig en ny forståelse af frihed, friheden i en persons indre".

Sakwa skriver: "Mens det tidligere var penge, som drev Khodorkovskij, havde han nu forstået, som han skrev, at 'når du er tvunget til at tænke på din kapitals skæbne hver vågen dag, så er det afhængighed, som betyder slaveri' ". Ja, ok kan man sige, Khodorkovskij havde nok før sin arrestation sørget for at lægge så mange penge til side, at han ikke kommer til at lide nød.

Sakwa konkluderer, at Khodorkovskij måtte blive et symbol på higen efter demokrati, "mens Putin havde lært, at 'oligarken' ikke var så farlig endda". Det har Putin hidtil fået ret $\mathrm{i}$.

Bogen giver en fremragende indsigt $i$ Putins regime, som indimellem kan synes for detaljeret, men djævlen ligger jo også i detaljen i Khodorkovskij-Jukos-affæren. Gennem Jukos-affæren tog staten magten over økonomien tilbage, men på en måde, som gjorde Putins moderniseringsprojekt af økonomien så godt som umuligt, fordi logikken bag var autoritær.

"Rusland havde indledt transitionen med et stort statsapparat, men en ekstraordinært svag stat", skriver Sakwa og påpeger, at Jukos-affæren tillod staten af afprivatisere. Det betød ikke en afslutning på konflikter om ressourcerne, men det ændrede fundamentalt spillereglerne. "Konflikterne blev nu primært udspillet inden for regimet, snarere end imellem uafhængige økonomiske aktører i samfundet".

\section{De politiske omkostninger}

Det er en del af forklaringen på, at korruptionen kun blev værre af Putins opgør med oligarkernes politiske indflydelse. Og magtspillet om Jukos havde enorme politiske konsekvenser. "Jukos-affæren gav signal til, at oligarkerne ikke længere kunne yde økonomisk støtte til politiske, uafhængige tænketanke eller medier, så uafhængige finansieringskilder tørrede ud og det undertrykte udviklingen af et autonomt civilt samfund".

Det var ifølge Sakwa forbavsende let at ødelægge Jukos og ekspropriere dets værdier, "men de politiske omkostninger var høje og overskyggede både Medvedevs præsidentperiode og Putins tilbagevenden til Kreml i 2012. Medvedev var ude af stand til at bryde med den uudtalte afhængighed af Putin og det forhold, at han ikke kunne løse Jukos-sagen formindskede hele hans præsidentskab".

Ifølge Sakwa er "Khodorkovskijs udfordring af magt- og ejendomssystemet, som er konsolideret i Putins tid, langt fra ovre".

At affæren markerer et vendepunkt i Ruslands nyere historie, bekræftede tidligere leder af Bank of Moscow, Andrej Borodin, i et interview til BBC i maj 2012. Borodin, der var blandt de mange, som drog i eksil i protest imod udviklingen, sagde, at 
med Jukos-affæren "havde siloviki og embedsmænd givet et klart signal om, at det samme som med Jukos kunne ske helt til tops. Men de fleste (herunder mig) syntes at have tænkt: Well, det vil ikke ramme os, hvis vi flyver lavt, ville vi klare os. Hvis vi ikke stak næsen frem og holdt os fra politik, så ville faren drive over”.

\section{En ny magtlogik}

Faren drev ikke over, for der blev tale om en helt ny magtlogik. Ifølge Borodin, som Sakwa refererer, så har foretagsomme erhvervsfolk skabt katastrofelufthavne, så de i hast kan forlade landet. Det er nu engang ikke den mest lovende forretningsatmosfære, som Sakwa påpeger. Jukos-affæren viste konfrontationen af to forskellige sfærers logik:
"Mens Khodorkovskij repræsenterede kravet om, at erhvervslivet havde ret til engagere sig politisk for at være med til at skabe de rette betingelser for sig selv, insisterede Putin på, at staten havde førerpositionen ikke bare i den politiske sfære, men også når det kom til de brede retningslinjer for den økonomiske politik. Putin gik endnu videre, da han også hævdede statens ret til en afgørende stemme ned i detaljer som energiledningers retning og adgang til ressourcer og markeder".

Når folk som Khodorkovskij er sat ud af spillet, og konflikter holdes inden for magtens døre, viser det meget om baggrunden for fraværet af retsstat i Rusland. En stærkt anbefalelsesværdig fortælling om et slag, som $\mathrm{Pu}$ tin vandt, men som Rusland tabte på. 